\title{
3D Culture of Circulating Tumor Cells for Evaluating Early Recurrence and Metastasis in Patients with Hepatocellular Carcinoma
}

This article was published in the following Dove Press journal: OncoTargets and Therapy

\author{
Cong-Li Hu ${ }^{1,2}$ \\ Yan-Jun Zhang ${ }^{3}$ \\ Xiao-Feng Zhang ${ }^{2}$ \\ Xiang $\mathrm{Fei}^{4}$ \\ Hai Zhang (D) $^{5}$ \\ Chun-Guang $\mathrm{Li}^{4}$ \\ Bin Sun $\mathbb{D}^{2}$
}

'Translational Medicine Center, Shanghai General Hospital, Shanghai Jiao Tong University School of Medicine, Shanghai, 201620, People's Republic of China;

${ }^{2}$ Department of Molecular Oncology, Eastern Hepatobiliary Surgical Hospital \& National Center for Liver Cancer, Second Military Medical University, Shanghai, 200438, People's Republic of China; ${ }^{3}$ School of Health and Social Care, Shanghai Urban Construction Vocational College, Shanghai, 2014I5, People's Republic of China; ${ }^{4}$ Department of Thoracic Surgery, Changhai Hospital, Second Military Medical University, Shanghai, 200438, People's Republic of China; ${ }^{5}$ Department of Pharmacy, Shanghai First Maternity and Infant Hospital, Tongji University School of Medicine, Shanghai, 201204, People's Republic of China
Correspondence: Bin Sun

Department of Molecular Oncology, Eastern Hepatobiliary Surgical Hospital \& National Center for Liver Cancer, Second Military Medical University, Shanghai, 200438, People's Republic of China Email sunbin05301984@outlook.com

Chun-Guang $\mathrm{Li}$

Department of Thoracic Surgery,

Changhai Hospital, Second Military

Medical University, 225 Changhai Road

Shanghai, 200438, People's Republic of

China

Email dr_lichunguang@sina.com
Purpose: Circulating tumor cells (CTCs) are considered to be a key factor involved in tumor metastasis. However, the isolation and culture of CTCs in vitro remains challenging, and their clinical application for predicting prognosis and survival is still limited. The development of accurate evaluating system for CTCs will benefit for clinical assessment of HCC.

Methods: Density gradient centrifugation and magnetic separation based on CD45 antibody were used to isolate CTCs. 3D culture was used to maintain and amplify CTCs and HCC cells. Cellular immunofluorescence was used to identify CTCs and spheroids. The cutoff value of CTC spheroid was calculated using X-tile software. The relationship between clinicopathological variables and CTC spheroids in HCC patients is analyzed. In vivo models were used to evaluate tumor growth and metastasis of CTC spheroids.

Results: Patient-derived CTCs/HCC cells were isolated and expanded to form spheroids using 3D culture. CTC spheroids could be used to predict short-term recurrence of CTCs compared with conventional CTC enumeration. Different cell lines exhibited different formation rates and grew to different sizes. Identification of CTC spheroids revealed that EpCAM and $\beta$-catenin were expressed in spheroids derived from HCC cells and in the HCC/CTCs. EpCAM-positive HCC cells exhibited improved spheroid formation in 3D culture and were more tumorigenic and likely to metastasize to the lung in vivo. Abnormal activation of the Wnt/ $\beta$-catenin signaling pathway was observed in EpCAM positive cells.

Conclusion: CTC spheroids could predict prognosis of HCC more precisely compared with conventional CTC enumeration. EpCAM may participate in the formation and survival of CTC spheroids which dependent on $\mathrm{Wnt} / \beta$-catenin signaling pathway.

Keywords: 3D culture, circulating tumor cells, early recurrence, metastasis, hepatocellular carcinoma

\section{Introduction}

Hepatocellular carcinoma (HCC) is one of the most common types of cancer worldwide $^{1,2}$ and usually develops as a result of liver cirrhosis., ${ }^{3,4}$ HCC is a highly aggressive cancer and is now the third leading cause of cancer-related death. Surgical resection, local ablation and liver transplantation are potentially curative for HCC. ${ }^{5}$ However, the majority of patients with HCC cannot undergo these procedures, as the cancer is usually diagnosed in the first instance at an advanced stage. Additionally, treatment using these methods is associated with higher postoperative recurrence rates, ${ }^{5-7}$ which jeopardizes overall survival of 
HCC patients. High-resolution imaging is the most common approach used to evaluate treatment, however, its sensitivity is quite low when a solid tumor is altered slightly. Imaging cannot detect early tumor cell metastases, as the tumor cells which are most likely to metastasize are present in low quantities during the initial stage when the cancer is still localized. Additionally, imaging cannot be used to predict prognosis of HCC patients. In recent years, several biomarkers, such as minichromosome maintenance complex component ${ }^{7,8}$ ubiquitin-specific peptidase $22^{9}$ and glypican $3^{10}$ have been identified to be potentially prognostic factors in patients with $\mathrm{HCC}$, and are awaiting large-scale clinical trials for evaluation.

Circulating tumor cells (CTCs) are defined as tumor cells that are shed into the bloodstream, which originated from solid tumors. These cells have the potential to promote thrombosis, ${ }^{11}$ metastasis to distant organs, ${ }^{12}$ and acquire resistance to anti-cancer drugs, ${ }^{13}$ and may thus be used to evaluate potential anti-cancer therapies. ${ }^{14,15}$ CTCs may also highlight the potential of blood-based biomarkers for prognostic prediction in several types of cancer. $^{15-18}$ At present, there is no standard protocol or method for identification and isolation of CTCs, although the CellSearch system, an epithelial cell adhesion molecule (EpCAM)-based capture method, has been approved by the US Food and Drug Administration (FDA) in 2004. Due at least in part to technological limitations, CTCs have not been incorporated into routine clinical practice. As for detection of CTCs in patients with HCC, EpCAMbased strategies are unsuitable, as only a small percentage of HCC cases are positive for EpCAM. ${ }^{19,20}$ Moreover, although an increasing number of studies have demonstrated the function of CTC enumeration in clinical oncology, currently available methods do not allow for determination of whether the isolated cells are responsible for the initiation and generation of metastases.

Clinical observations and animal model studies have suggested that although thousands of tumor cells disseminate into the circulation, only a very small fraction of CTCs give rise to distant metastases, a phenomenon regarded as "metastatic inefficiency".14,21,22 Isolated CTCs are hypothesized to be viable cells which can be maintained in an in vitro manner. In our recent study, $\mathrm{HCC}$ patient-derived CTCs were expanded to form spheroids using $3 \mathrm{D}$ cell cultures grown in a specific media. This in vitro cell culture model was shown to reflect human tumors in a more accurate manner than conventional monolayer cultures, or 3D cultures using immortalized cell lines, as the use of primary cells more accurately mimicked the properties of the tumor in vivo. Thus, it was hypothesized that CTCs may be used to form spheroids and that they may be responsible for the development of a metastasis. Spheroid culture of CTCs may provide more reliable information regarding the prognosis of a patient when used alongside CTC enumeration in all HCC subtypes. The present study explored whether spheroid formation of CTCs was more relevant to disease progression and survival compared with CTC enumeration, and identified which CTC subpopulations, based on molecular characterization, possessed an aggressive phenotype and formed spheroids.

\section{Materials and Methods Ethics Statement}

The use of human tissues, blood samples, and clinical data was approved by the Biomedical Ethics Committee of Eastern Hepatobiliary Surgery Hospital, Second Military Medical University (Shanghai, China). All patients and healthy volunteers provided informed written consent, which was conducted in accordance with the declaration of Helsinki.

\section{Patients and Sample Collection}

Between May 2012 and June 2013, peripheral blood samples were collected from 106 patients with HCC, 37 patients with benign liver diseases (30 patients with intrahepatic bile duct stones, 7 patients with hepatic hemangioma) and 12 healthy volunteers. All patients were diagnosed histopathologically. The clinicopathological characteristics of all patients are summarized in Table 1. Blood was drawn from each subject and collected in a BD Vacutainer tube containing sodium heparin (Becton, Dickinson and Company). The samples were stored at $4^{\circ} \mathrm{C}$ and processed within $6 \mathrm{~h}$ following collection. Peripheral blood was collected for CTC assays in polyethylene tubes containing EDTA (Greiner Bio-One $\mathrm{GmbH}$ ). All patients were followed-up postoperatively by the same team of surgeons. A short-term follow-up was performed as previously described. The median follow-up time was 15.8 \pm 6.0 months (range, 1-24 months).

\section{CTC Enrichment}

CTC enrichment of whole blood samples was performed as described previously. ${ }^{23}$ Briefly, following density 
Table I Clinical Characteristics of HCC Patients and Correlation with CTC Counts

\begin{tabular}{|c|c|c|c|c|}
\hline $\begin{array}{l}\text { Clinical } \\
\text { Characteristics }\end{array}$ & $\begin{array}{c}\text { No. of } \\
\text { Patients } \\
(n=106)\end{array}$ & $\begin{array}{c}\text { CTC } \\
(+) \\
(n=60)\end{array}$ & $\begin{array}{c}\text { CTC } \\
(-) \\
(n=46)\end{array}$ & $p$ \\
\hline $\begin{array}{l}\text { Age, years } \\
\quad \leq 50 \\
>50\end{array}$ & $\begin{array}{l}55 \\
51\end{array}$ & $\begin{array}{l}33 \\
27\end{array}$ & $\begin{array}{l}22 \\
24\end{array}$ & 0.464 \\
\hline $\begin{array}{l}\text { Sex } \\
\qquad \text { Male } \\
\text { Female }\end{array}$ & $\begin{array}{l}83 \\
23\end{array}$ & $\begin{array}{l}49 \\
11\end{array}$ & $\begin{array}{l}34 \\
12\end{array}$ & 0.337 \\
\hline $\begin{array}{l}\text { HBsAg } \\
\text { Negative } \\
\text { Positive }\end{array}$ & $\begin{array}{l}20 \\
86\end{array}$ & $\begin{array}{c}9 \\
51\end{array}$ & $\begin{array}{l}11 \\
35\end{array}$ & 0.245 \\
\hline $\begin{array}{l}\text { Child-Pugh score } \\
\text { A } \\
\text { B }\end{array}$ & $\begin{array}{c}102 \\
4\end{array}$ & $\begin{array}{c}57 \\
3\end{array}$ & $\begin{array}{c}45 \\
1\end{array}$ & 0.449 \\
\hline $\begin{array}{l}\text { Liver cirrhosis } \\
\text { No } \\
\text { Yes }\end{array}$ & $\begin{array}{l}32 \\
74\end{array}$ & $\begin{array}{l}17 \\
43\end{array}$ & $\begin{array}{l}15 \\
31\end{array}$ & 0.635 \\
\hline $\begin{array}{c}\text { ALT, U/L } \\
\quad \leq 75 \\
>75\end{array}$ & $\begin{array}{l}83 \\
23\end{array}$ & $\begin{array}{l}44 \\
16\end{array}$ & $\begin{array}{c}39 \\
7\end{array}$ & 0.156 \\
\hline $\begin{array}{l}\text { AFP, } \mathrm{ng} / \mathrm{mL} \\
\quad \leq 400 \\
>400\end{array}$ & $\begin{array}{l}50 \\
56\end{array}$ & $\begin{array}{l}23 \\
37\end{array}$ & $\begin{array}{l}27 \\
19\end{array}$ & 0.037 \\
\hline $\begin{array}{l}\text { No. of tumors } \\
\text { Single } \\
\text { Multiple }\end{array}$ & $\begin{array}{l}96 \\
10\end{array}$ & $\begin{array}{c}54 \\
6\end{array}$ & $\begin{array}{c}42 \\
4\end{array}$ & 0.820 \\
\hline $\begin{array}{l}\text { Tumor size, cm } \\
\qquad 5 \\
>5\end{array}$ & $\begin{array}{l}71 \\
35\end{array}$ & $\begin{array}{l}42 \\
18\end{array}$ & $\begin{array}{l}29 \\
17\end{array}$ & 0.450 \\
\hline $\begin{array}{l}\text { Tumor } \\
\text { encapsulation } \\
\text { Complete } \\
\text { None }\end{array}$ & $\begin{array}{l}80 \\
26\end{array}$ & $\begin{array}{l}41 \\
19\end{array}$ & $\begin{array}{c}39 \\
7\end{array}$ & 0.05 I \\
\hline $\begin{array}{l}\text { Satellite lesion } \\
\text { No } \\
\text { Yes }\end{array}$ & $\begin{array}{l}89 \\
17\end{array}$ & $\begin{array}{l}45 \\
15\end{array}$ & $\begin{array}{c}44 \\
2\end{array}$ & 0.004 \\
\hline $\begin{array}{l}\text { Vascular invasion } \\
\text { No } \\
\text { Yes }\end{array}$ & $\begin{array}{l}51 \\
55\end{array}$ & $\begin{array}{l}21 \\
39\end{array}$ & $\begin{array}{l}30 \\
16\end{array}$ & 0.002 \\
\hline $\begin{array}{l}\text { Edmondson } \\
\text { stage } \\
\text { I-II } \\
\text { III-IV }\end{array}$ & $\begin{array}{l}66 \\
40\end{array}$ & $\begin{array}{l}31 \\
29\end{array}$ & $\begin{array}{l}35 \\
11\end{array}$ & 0.010 \\
\hline
\end{tabular}

(Continued)
Table I (Continued).

\begin{tabular}{|l|c|c|c|c|}
\hline $\begin{array}{l}\text { Clinical } \\
\text { Characteristics }\end{array}$ & $\begin{array}{c}\text { No. of } \\
\text { Patients } \\
(\mathbf{n}=106)\end{array}$ & $\begin{array}{c}\text { CTC } \\
(+) \\
(\mathbf{n}=\mathbf{6 0})\end{array}$ & $\begin{array}{c}\text { CTC } \\
(\mathbf{-}) \\
(\mathbf{n}=\mathbf{4 6})\end{array}$ & $\mathbf{p}$ \\
\hline BCLC stage & 88 & 48 & 40 & 0.344 \\
0+A & 18 & 12 & 6 & \\
B+C & 62 & 26 & 36 & $<0.001$ \\
\hline Recurrence & 44 & 34 & 10 & \\
No & & & & \\
Yes & & &
\end{tabular}

gradient centrifugation, CTCs were enriched by extracting CD45-expressing leukocytes with magnetically labeled anti-CD45 monoclonal antibodies (130-109-682, Miltenyi Biotec) according to the manufacturer's protocol. The remaining cells were cytocentrifuged on poly-lysinecoated slides for identification and enumeration of CTCs, or resuspended in $150 \mu \mathrm{L}$ DMEM (high glucose) (Gibco; Thermo Fisher Scientific, Inc.) for the in vitro 3D culture of CTCs.

\section{Identification and Enumeration of CTCs}

The method used in the present was the same as that described previously in more detail. ${ }^{24}$ Briefly, the slides prepared from blood samples were incubated with the primary antibodies (mouse anti-ASGPR antibody sc52623, Santa Cruz; or rabbit anti-CPS1 antibody ab128942, Abcam then stained with the Cy3-conjugated goat anti-mouse $\operatorname{IgG}$ antibody and the FITC-conjugated goat anti-rabbit $\operatorname{IgG}$ antibody (A0521 and A0562, Beyotime Institute of Biotechnology), and co-stained with DAPI. The stained slides were viewed under a fluorescence microscope (IX71; Olympus Corporation), and images were captured from positively stained CTCs and control slides using the same gain and exposure times. The ASGPR/CPS1 and DAPI-stained cells that exhibited morphological features of malignant cells (large cell size, high nuclear to cytoplasmic ratio, and visible nucleoli) were considered HCC/CTCs. Cell counts are expressed as the number of cells per $5 \mathrm{~mL}$ blood.

\section{In vitro Conventional Cell Culture and 3D Culture}

The human hepatoma cells PLC/PRF/5, Hep3B, Huh-7 and HCCLM3 were obtained and cultured as previously 
described. ${ }^{23}$ All the cells were identified and confirmed by STR profiling. The enriched CTCs were cultured using a 3D cell culture assay as described previously. ${ }^{13,25}$ Briefly, Matrigel (BD Biosciences) was thawed according to the manufacturer's protocol and mixed with an equivalent volume of CTC-containing DMEM. When the hepatoma cell lines were used for $3 \mathrm{D}$ culture, $1 \times 10^{3}$ cells suspended in DMEM was mixed with Matrigel. The prepared mixture was then incubated in a 24-well plate for 30 $\min$ at $37^{\circ} \mathrm{C}$. Subsequently, $500 \mu \mathrm{L}$ DMEM supplemented with $10 \%$ FBS was added to the plate, and the media was replaced every 2 days. Spheroid formation was observed under a microscope every day and counted on day 7 . A spheroid was defined as a $3 \mathrm{D}$ cell structure $>100 \mu \mathrm{m}$ in diameter, based on images taken on a microscope.

\section{Immunofluorescence and Immunohistochemistry Staining}

Cell spheroids were gently detached, picked and fixed on glass slides with $4 \%$ paraformaldehyde. The cells were blocked using normal goat serum. Slides were incubated for $1 \mathrm{~h}$ with the primary antibodies, including mouse anti-human CPS1 (ab128942, Abcam), mouse anti-human ASGPR, rat antihuman CD45 (sc52623 and sc19597 both from Santa Cruz Biotechnology Inc.), rabbit anti-human EpCAM and rabbit anti-human $\beta$-catenin (ab221552 and ab32572 all from Abcam). CPS1 and ASGPR antibodies were used for detection of hepatocytes, ${ }^{23,24}$ a CD45 antibody was used for detection of hematological cells, ${ }^{26}$ and EpCAM and $\beta$-catenin antibodies were used for detection of stem-like cancer cells. ${ }^{27,28}$ After washing 3 times with PBS, the secondary antibodies, including the Cy3-conjugated goat anti-mouse/rabbit IgG (A0521 and A0562, Beyotime Institute of Biotechnology) or Alexa Fluor 488-conjugated rabbit anti-rat IgG (A21210, Invitrogen; Thermo Fisher Scientific, Inc.) antibodies were added and incubated at room temperature for $40 \mathrm{~min}$. Cells were then counterstained with DAPI (D9542, Sigma-Aldrich; Merck $\mathrm{KGaA}$ ) and images were captured using an Olympus-IX71 fluorescent microscope (Olympus Corporation).

Tumor tissues from animal models were embedded in paraffin and cut into $4 \mu \mathrm{m}$ thick sections. Tissue sections were deparaffinized, rehydrated and treated with $3 \% \mathrm{H}_{2} \mathrm{O}_{2}$ for $15 \mathrm{~min}$ to inhibit endogenous peroxidase activity. Following heat-induced epitope retrieval in $10 \mathrm{mM}$ citrate buffer ( $\mathrm{pH}$ 6.0) in a microwave for $15 \mathrm{~min}$, the slides were incubated at $4^{\circ} \mathrm{C}$ overnight with the pre-diluted primary antibodies (Ki67, EpCAM and $\beta$-catenin; ab16667, ab221552 and ab32572, all from Abcam). After incubation with a secondary antibody, the signal was developed using 3,3'-diaminobenzidine tetrachloride. Tissues were imaged using a microscope.

\section{Knockdown of EpCAM Using Small Interfering (si)RNA}

EpCAM was knocked-down by transfecting the cultured cells using SMARTpool siRNAs targeting EpCAM (GE Healthcare) and Lipofectamine ${ }^{\circledR} 2000$ (Thermo Fisher Scientific, Inc.). siRNA-NC was used as control. Transfections were performed according to the manufacturer's protocol.

\section{Western Blot Analysis}

Total proteins were prepared from harvested cells and resolved $(20 \mu \mathrm{g} / \mathrm{lane})$ on SDS-gels using SDS-PAGE. The resolved proteins were transferred to PVDF membranes. Anti-EpCAM and anti- $\beta$-catenin primary antibodies were used (both from Abcam). GAPDH antibodies and all secondary antibodies were obtained from Santa Cruz Biotechnology, Inc. Immunoreactive proteins were visualized using an enhanced chemiluminescence detection system (Sigma-Aldrich; Merck KGaA), by exposing $\mathrm{X}$-ray films to the treated membranes.

The cytoplasmic protein and the nuclear protein were extracted according to instructions of nuclear and cytoplasmic extraction reagents kit (Beyotime, Jiangsu, China). GAPDH was used as internal control.

\section{Colony Formation Assay}

Cell spheroids were enzymatically dissociated using dispase (BD Biosciences). Cell viability was determined by staining the cells with trypan blue, and the unstained cells were counted. If cell viability was $>95 \%$, then the cultures were used for the colony formation assay. A 6-well plate was pre-coated with Matrigel (BD Biosciences), and cells were seeded in DMEM with $10 \%$ FBS at a density of $1 \times 10^{3}$ cells/well. After 7 days, the number of colonies stained with crystal violet (Sigma-Aldrich; Merck KGaA) was counted under a microscope, and representative images were taken.

\section{In vivo Tumor Growth and Metastasis Model}

$\mathrm{BALB} / \mathrm{c}$ male nude mice (6-8 weeks old) were purchased from Shanghai Laboratory Animal Center, Chinese Academy of Sciences. Mice were raised under pathogen-free 
conditions. All in vivo experiments were performed in accordance with guidelines and approved by the Animal Care Committee of Second Military Medical University (Shanghai, China). Briefly, for the subcutaneously injected tumor model, $5 \times 10^{5}$ HCC spheroids were subcutaneously injected into the flanks of mice. Tumor volume was calculated using the following formula: length $\mathrm{x}$ width $^{2} \times 0.5$. After 6 weeks, the tumors from each mouse was isolated. For the lung metastasis model, $1 \times 10^{4} \mathrm{HCC}$ spheroids were injected into the tail veins of mice. The mice were monitored for 6 weeks for lung metastases using hematoxylin-eosin (H\&E) staining.

\section{Statistical Analysis}

Data are expressed as the median \pm standard error of the mean or as a percentage. Differences between groups were compared using a Student's $t$-test or a one-way ANOVA. Spearman's rank correlation analysis was used for determining the nonparametric correlations. Survival analysis was estimated using the Kaplan-Meier survival method. SPSS version 12.0 (SPSS Inc.) was used for all statistical analyses. $\mathrm{P}<0.05$ was considered to indicate a statistically significant difference.

\section{Results}

\section{Development of the 3D Cell Culture Assay for Circulating HCC Cells}

Our previous study showed that CTCs from patients with HCC patients were difficult to maintain and amplify using conventional cell culture methods. ${ }^{29}$ Thus, a 3D cell culture assay was used to overcome the current limitations of 2D culture methods. 3D cell structures or spheroids increase in size over time at different rates depending on the HCC cell line or the primary cells obtained from patients. Spheroids remain healthy until at least day $12-14$ of culture (Figures $1 \mathrm{~A}$ and $\underline{\mathrm{S} 1}$ ). A healthy spheroid was defined as one in which the cell mass remained tightly packed, was $>100 \mu \mathrm{m}$ in diameter and exhibited minimal shedding of apoptotic cells. Spheroids were observed every day and counted on Day 7. The results revealed that CTC spheroids were not observed in cultures obtained from the healthy volunteers and patients with benign liver disease (including intrahepatic bile duct stones and liver hemangioma) group. CTC spheroids $(16.3 \pm 22.9$, range: 0-88) were observed in $91.67 \%$ (55/60) of cultures developed using cells obtained from CTC positive HCC patients (38.6 \pm 39.4 , range: $2-178)$.

\section{Identification of CTC Spheroids}

Immunofluorescence staining results showed that all cultured spheroids that formed were derived from hepatocytes expressing hepatocyte-specific markers (CPS1 and ASGPR). The CD $45^{+}$lymphocytes were gradually eliminated in the in vitro 3D culture (Figure 1B). In addition, EpCAM, which is considered an epithelial stem cell marker, and the cell-cell adhesion molecule $\beta$ catenin were detected in the CTC spheroids. There was low or no expression of EpCAM and $\beta$-catenin expression in single CTCs. Thus, these data suggest that CTC spheroids were formed by stem cell-like CTCs and aggregated together to avoid rapid clearing, thus enhancing survival and metastatic potential. CTC spheroids may thus be used to evaluate early recurrence and identify therapeutic targets.

\section{CTC Spheroids May Serve a Significant Role in Predicting Short-Term Recurrence}

Follow-up of patients showed that the $\mathrm{CTC}^{+}$patients exhibited earlier short-term recurrence time (Figure 2A). However, correlation analysis found that there was no correlation between CTC enumeration and spheroid formation in the same patient $(\mathrm{R}=0.1649)$ (Figure 2B and $\mathrm{C}$ ). Due to the heterogeneity of tumor cells and apoptosis caused by circulating shear forces, simple enumeration of CTCs to evaluate prognostic potential is controversial. $3 \mathrm{D}$ cell culture results found that CTC spheroids formed from cells obtained from patients with HCC prior to surgery could effectively predict early recurrence (Figure 3A). A total of 60 patients with HCC with positive circulating $\mathrm{HCC}$ cells were recruited in the present study. The optimal cutoff value of CTC spheroid count was 16, calculated using X-tile version 3.6.1 (Yale University). The patients with $>16$ spheroids exhibited significantly shorter early recurrence time $(\mathrm{P}<0.0001$; Figure 3B). The AUC for CTC spheroid counts $\geq 16$ was 0.744 , with a sensitivity of $96.77 \%$ and specificity of 70.45\% ( $\mathrm{P}<0.001 ; 95 \% \mathrm{CI}, 0.645-0.843)$. Compared with other clinical indices, CTC spheroid counts $\geq 16$ was the most relevant factor for predicting early recurrence in $\mathrm{HCC}$ (AUCs with $95 \% \mathrm{CI}$ for time to recurrence; $\mathrm{P}<0.05$ vs CTC spheroid counts $\geq 16$; Figure $3 \mathrm{C}$ ). The clinicopathological variables between CTC enumeration and CTC spheroids in HCC patients are compared in Tables 1 and 2. CTC enumeration was significantly correlated with serum AFP $(\mathrm{P}=0.037)$, satellite lesion $(\mathrm{P}=0.004)$, vascular invasion 
A

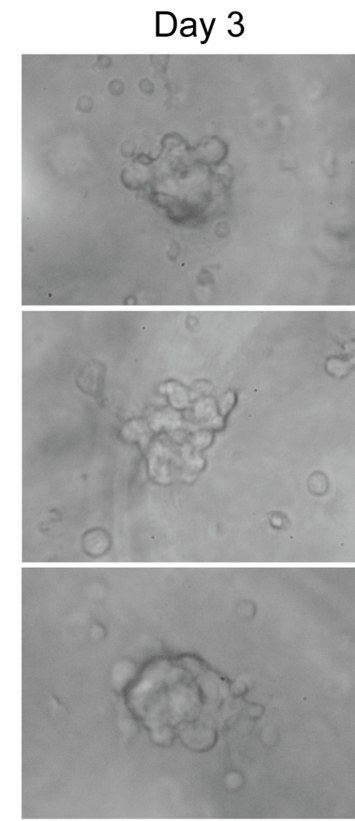

Day 5

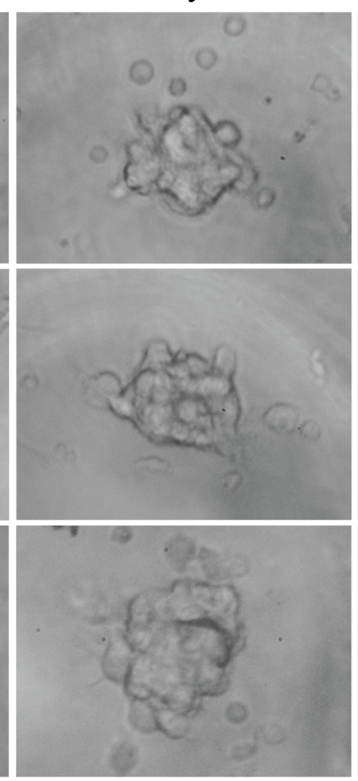

Day 7

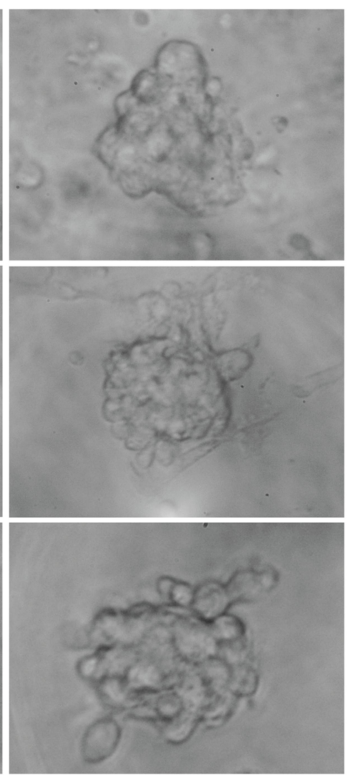

Day 10

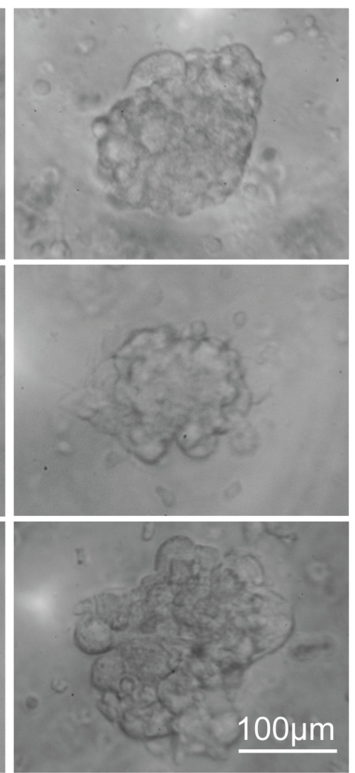

$\mathbf{B}$

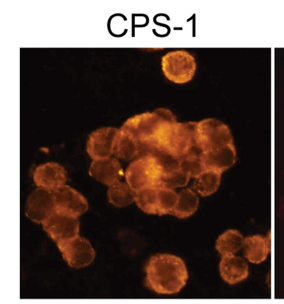

ASGPR

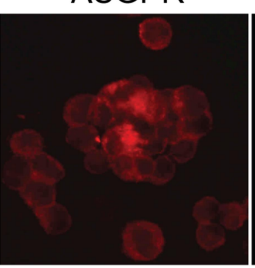

ASGPR

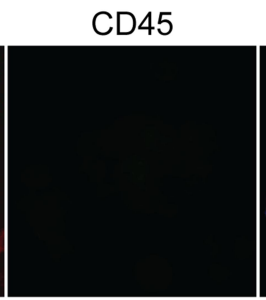

DAPI
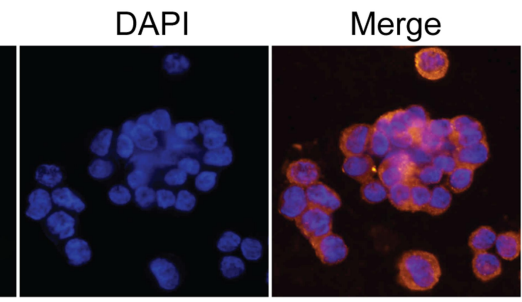

DAPI

Merge
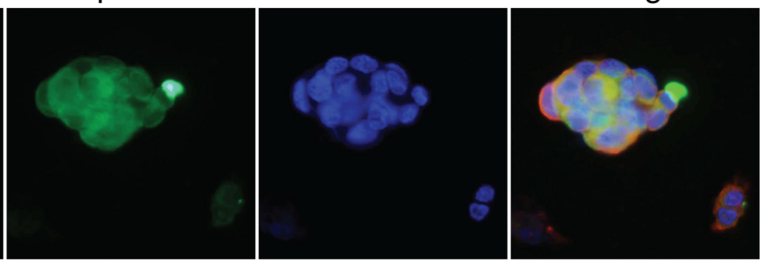

White light
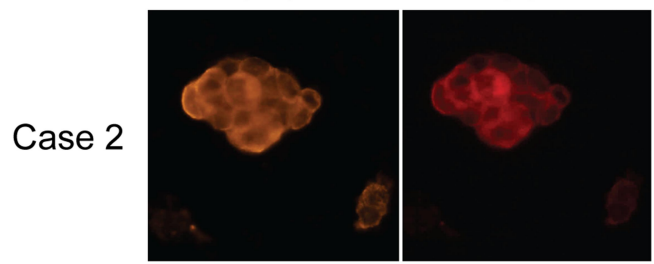

$\beta$-catenin

DAPI

Merge
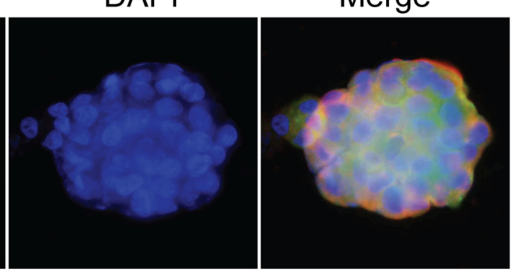

White light
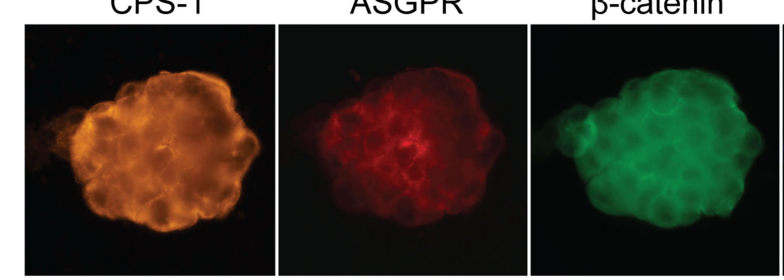

Figure I Culture and identification of CTC spheroids from the blood sample of patients with HCC. (A) Typical images of CTC spheroids from the blood samples of patients with HCC after different periods of culturing. (B) Identification of CTC spheroids from the blood samples of patients with HCC using immunofluorescence analysis. Abbreviations: CTC, circulating tumor cell; HCC, hepatocellular carcinoma.

$(\mathrm{P}=0.002)$, Edmondson stage $(\mathrm{P}=0.010)$ and recurrence $(\mathrm{P}<0.001)$. The $\mathrm{CTC}$ spheroids were significantly correlated with satellite lesion $(\mathrm{P}<0.001)$, vascular invasion $(\mathrm{P}=0.008)$, Edmondson stage $(\mathrm{P}=0.005)$ and recurrence $(\mathrm{P}=0.007)$. Based on the univariate and multivariate analysis, CTC spheroids was one of the independent variables for predicting recurrence (Table 3).

\section{D Cell Culture Assay for HCC Cells in vitro}

3D culture assay was used to detect spheroid formation capacity of four HCC cell lines: HCCLM3, HepG2, PLC/ $\mathrm{PRF} / 5$ and Huh7. All four HCC cell lines were capable of forming spheroids when cultured in the 3D culture conditions. However, the sizes of the spheroids and formation 

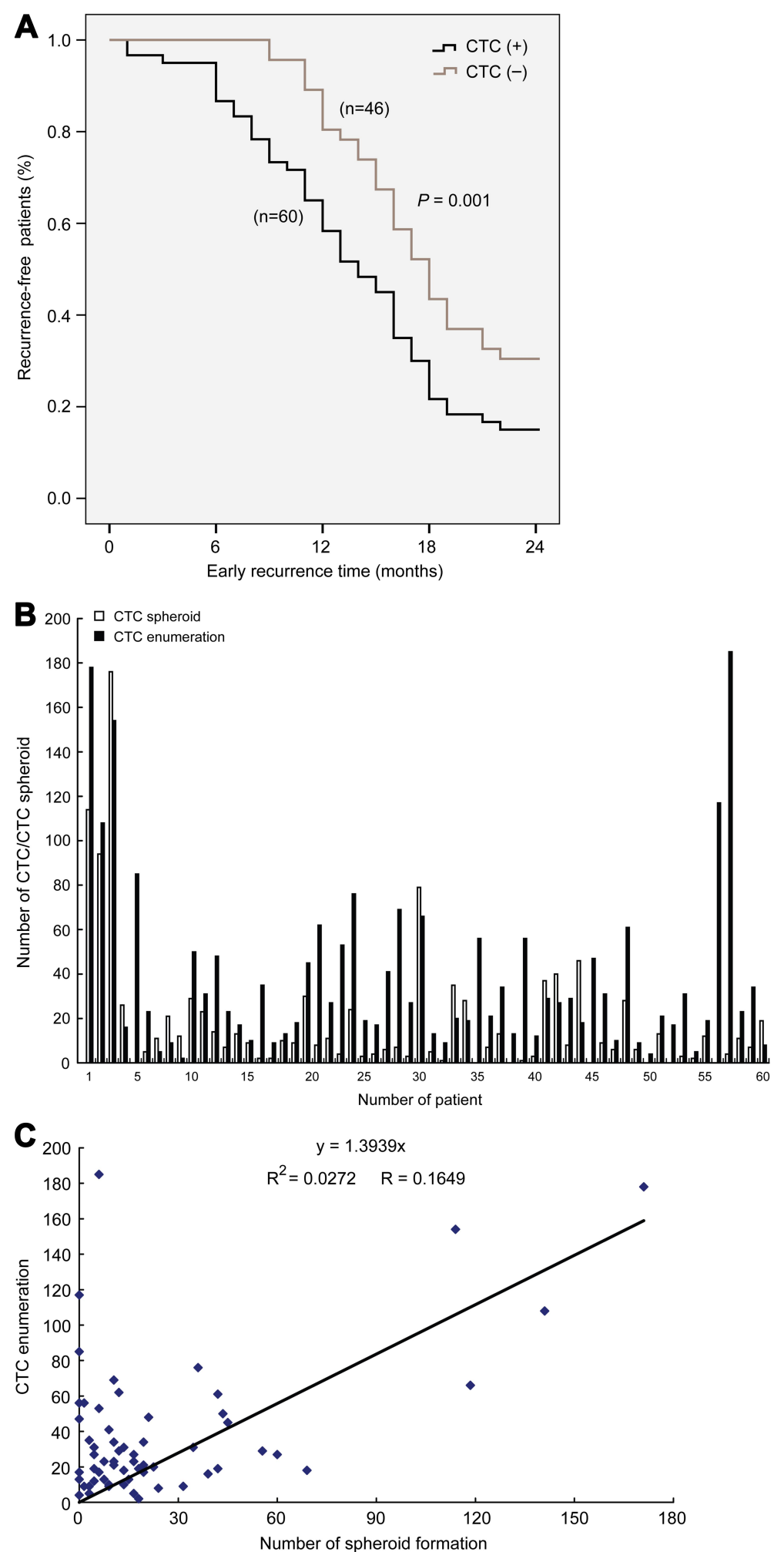

Figure 2 Correlation analysis between CTC enumeration and CTC spheroid formation in patients with HCC. (A) Early recurrence curves of patients with HCC with CTC $(+)(n=60)$ and CTC $(-)(n=46) . P=0.001)$. (B) Paired CTC enumeration and the presence of CTC spheroids in patients with HCC with CTCs ( $=60)$. (C) Correlation analysis between CTC enumeration and the presence of CTC spheroids. $R=0.1649$. Abbreviations: CTC, circulating tumor cell; HCC, hepatocellular carcinoma. 

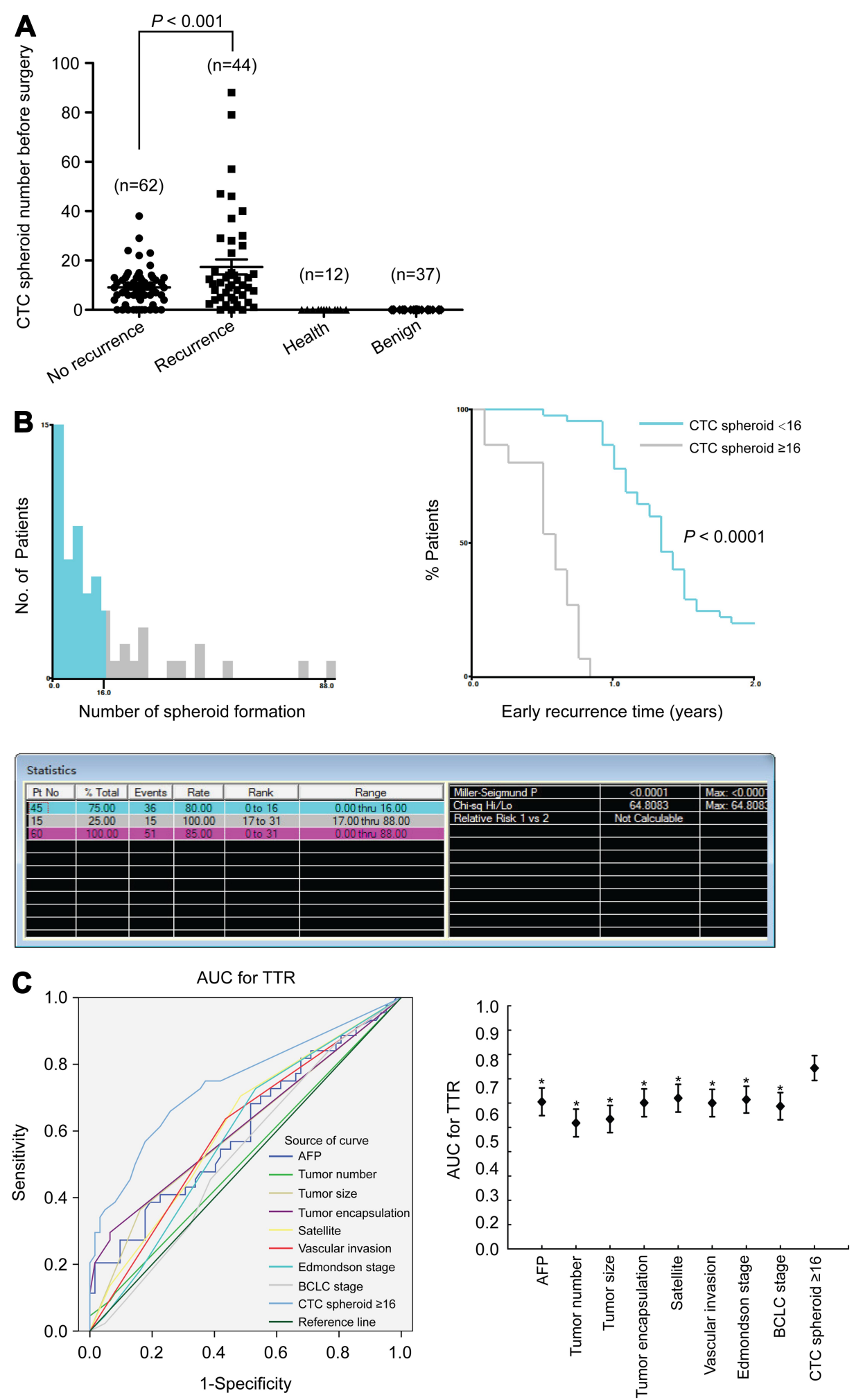

Figure 3 The presence of CTC spheroids are significantly correlated with early recurrence. (A) Distribution of CTC spheroids in early recurrent patients. P $<0.001$. (B) Optimal cutoff value of CTC spheroid counts was selected using X-tile software. (C) Predictive ability of a CTC spheroid count $\geq 16$ was compared with other clinical parameters using receiver operating characteristic curves in 106 patients with HCC. The area under the curve with $95 \%$ confidence intervals for TTR are also shown. $* \mathrm{P}<0.05$ vs CTC spheroid count $\geq 16$.

Abbreviations: CTC, circulating tumor cell; TTR, time to recurrence. 
Table 2 Clinical Characteristics of HCC Patients and Correlation with CTC Spheroids Counts

\begin{tabular}{|c|c|c|c|c|}
\hline $\begin{array}{l}\text { Clinical } \\
\text { Characteristics }\end{array}$ & $\begin{array}{l}\text { No. of } \\
\text { Patients } \\
(n=60)\end{array}$ & $\begin{array}{c}\text { CTC } \\
\text { Spheroids } \\
\geq 16(n=15)\end{array}$ & $\begin{array}{c}\text { CTC } \\
\text { Spheroids } \\
<16(n=45)\end{array}$ & $p$ \\
\hline $\begin{array}{l}\text { Age, years } \\
\quad \leq 50 \\
>50\end{array}$ & $\begin{array}{l}33 \\
27\end{array}$ & $\begin{array}{l}9 \\
6\end{array}$ & $\begin{array}{l}24 \\
21\end{array}$ & 0.653 \\
\hline $\begin{array}{l}\text { Sex } \\
\qquad \text { Male } \\
\text { Female }\end{array}$ & $\begin{array}{l}49 \\
11\end{array}$ & $\begin{array}{l}12 \\
3\end{array}$ & $\begin{array}{c}37 \\
8\end{array}$ & 0.847 \\
\hline $\begin{array}{l}\mathrm{HBsAg} \\
\text { Negative } \\
\text { Positive }\end{array}$ & $\begin{array}{c}9 \\
51\end{array}$ & $\begin{array}{c}4 \\
11\end{array}$ & $\begin{array}{c}5 \\
40\end{array}$ & 0.144 \\
\hline $\begin{array}{l}\text { Child-Pugh score } \\
\text { A } \\
\text { B }\end{array}$ & $\begin{array}{c}57 \\
3\end{array}$ & $\begin{array}{l}13 \\
2\end{array}$ & $\begin{array}{c}44 \\
1\end{array}$ & 0.087 \\
\hline $\begin{array}{l}\text { Liver cirrhosis } \\
\text { No } \\
\text { Yes }\end{array}$ & $\begin{array}{l}17 \\
43\end{array}$ & $\begin{array}{c}5 \\
10\end{array}$ & $\begin{array}{l}12 \\
33\end{array}$ & 0.620 \\
\hline $\begin{array}{c}\text { ALT, U/L } \\
\leq 75 \\
>75\end{array}$ & $\begin{array}{l}44 \\
16\end{array}$ & $\begin{array}{l}9 \\
6\end{array}$ & $\begin{array}{l}35 \\
10\end{array}$ & 0.178 \\
\hline $\begin{array}{l}\text { AFP, ng/mL } \\
\quad \leq 400 \\
>400\end{array}$ & $\begin{array}{l}23 \\
37\end{array}$ & $\begin{array}{c}3 \\
12\end{array}$ & $\begin{array}{l}20 \\
25\end{array}$ & 0.092 \\
\hline $\begin{array}{l}\text { No. of tumors } \\
\text { Single } \\
\text { Multiple }\end{array}$ & $\begin{array}{c}54 \\
6\end{array}$ & $\begin{array}{c}13 \\
2\end{array}$ & $\begin{array}{c}41 \\
4\end{array}$ & 0.619 \\
\hline $\begin{array}{l}\text { Tumor size, cm } \\
\quad \leq 5 \\
>5\end{array}$ & $\begin{array}{l}42 \\
18\end{array}$ & $\begin{array}{l}10 \\
5\end{array}$ & $\begin{array}{l}32 \\
13\end{array}$ & 0.745 \\
\hline $\begin{array}{l}\text { Tumor } \\
\text { encapsulation } \\
\text { Complete } \\
\text { None }\end{array}$ & $\begin{array}{l}41 \\
19\end{array}$ & $\begin{array}{l}8 \\
7\end{array}$ & $\begin{array}{l}33 \\
12\end{array}$ & 0.149 \\
\hline $\begin{array}{l}\text { Satellite lesion } \\
\text { No } \\
\text { Yes }\end{array}$ & $\begin{array}{l}45 \\
15\end{array}$ & $\begin{array}{c}4 \\
11\end{array}$ & $\begin{array}{c}41 \\
4\end{array}$ & $<0.001$ \\
\hline $\begin{array}{l}\text { Vascular invasion } \\
\text { No } \\
\text { Yes }\end{array}$ & $\begin{array}{l}21 \\
39\end{array}$ & $\begin{array}{c}1 \\
14\end{array}$ & $\begin{array}{l}20 \\
25\end{array}$ & 0.008 \\
\hline $\begin{array}{l}\text { Edmondson stage } \\
\text { I-II } \\
\text { III-IV }\end{array}$ & $\begin{array}{l}31 \\
29\end{array}$ & $\begin{array}{c}3 \\
12\end{array}$ & $\begin{array}{l}28 \\
17\end{array}$ & 0.005 \\
\hline $\begin{array}{c}\mathrm{BCLC} \text { stage } \\
0+\mathrm{A}\end{array}$ & 48 & 11 & 37 & 0.456 \\
\hline
\end{tabular}

Table 2 (Continued).

\begin{tabular}{|l|c|c|c|c|}
\hline $\begin{array}{l}\text { Clinical } \\
\text { Characteristics }\end{array}$ & $\begin{array}{c}\text { No. of } \\
\text { Patients } \\
(\mathbf{n = 6 0 )}\end{array}$ & $\begin{array}{c}\text { CTC } \\
\text { Spheroids } \\
\geq 16(n=15)\end{array}$ & $\begin{array}{c}\text { CTC } \\
\text { Spheroids } \\
<16(\mathbf{6}=45)\end{array}$ & $p$ \\
\hline B+C & 12 & 4 & 8 & \\
\hline Recurrence & & 2 & 24 & 0.007 \\
No & 26 & 13 & 21 & \\
Yes & 34 & 13 & \\
\hline
\end{tabular}

rates did differ amongst the HCC cell lines. HepG2 exhibited the highest spheroid formation rate, followed by Huh7, then HCCLM3 and finally PLC/PRF/5. Huh7 cells formed the largest spheroids (Figure 4A). Immunofluorescence analysis showed that $\mathrm{EpCAM}$ and $\beta$ catenin were expressed in spheroids formed from the $\mathrm{HCC}$ cells, consistent with the spheroids formed of HCC/CTCs (Figure 4B). We cultured HCC cells by using conventional method and 3D method, and extracted protein from cytoplasm and nucleus, respectively. The results of Western blot assay showed that the expression of EpCAM was increased in 3D culture group. The expression of $\beta$ catenin in the spheroids was significantly enhanced in both cytoplasm and nucleus compared with conventional cultured HCC cells simultaneously (Figure S2).

\section{EpCAM Positive HCC Cells Exhibit Better Spheroid Formation Ability Under the 3D Culture Conditions}

To determine whether EpCAM participated in spheroid formation, the EpCAM-positive HCC cells were initially isolated by immunomagnetic sorting prior to the 3D culture. After 7 days of culture, the EpCAM-positive HCC cells exhibited significantly better spheroid formation compared with the EpCAM-negative HCC cells. HCC cells in which EpCAM expression was knocked down using siRNA exhibited reduced spheroid formation (Figure 5A). The soft agar colony formation assay revealed that the EpCAM-positive cells presented better growth ability, and this was reduced by the siRNAmediated knockdown of EpCAM (Figure 5B).

EpCAM and $\beta$-catenin protein expression in the HCC cells was detected by Western blotting. The results showed that $\beta$-catenin expression was higher in the EpCAMpositive cells and decreased when EpCAM expression was knocked down (Figure 5C). 
Table 3 Univariate and Multivariate Cox Proportional Regression Analysis of Factors Associated with Recurrence

\begin{tabular}{|c|c|c|c|c|}
\hline \multirow[t]{2}{*}{ Variables } & \multicolumn{2}{|c|}{ Univariate Analysis } & \multicolumn{2}{|c|}{ Multivariate Analysis } \\
\hline & HR (95\% Cl) & $\boldsymbol{P}$ & HR (95\% Cl) & $\boldsymbol{P}$ \\
\hline Age, $>50$ years versus $\leq 50$ & $0.64(0.35-1.17)$ & 0.151 & NA & NA \\
\hline Sex, male versus female & $0.90(0.43-1.88)$ & 0.786 & NA & NA \\
\hline $\mathrm{HBs} A g$, positive versus negative & $0.65(0.32-|.3|)$ & 0.229 & NA & NA \\
\hline Liver cirrhosis, yes versus no & $1.07(0.57-2.03)$ & 0.828 & NA & NA \\
\hline Child-Puge score, $B$ versus $A$ & $1.43(0.35-5.94)$ & 0.618 & NA & NA \\
\hline $\mathrm{ALT},>75 \mathrm{U} / \mathrm{L}$ versus $\leq 75 \mathrm{U} / \mathrm{L}$ & $\mathrm{I} .58(0.8 \mathrm{I}-3.07)$ & 0.175 & NA & NA \\
\hline AFP, $>400 \mathrm{ng} / \mathrm{mL}$ versus $\leq 400 \mathrm{ng} / \mathrm{mL}$ & $1.96(1.05-3.66)$ & 0.034 & $1.27(0.59-2.75)$ & 0.542 \\
\hline No. of tumors, multiple versus single & $1.05(0.4 I-2.66)$ & 0.923 & NA & NA \\
\hline Tumor size, $>5 \mathrm{~cm}$ versus $\leq 5 \mathrm{~cm}$ & $0.90(0.47-1.69)$ & 0.738 & NA & NA \\
\hline Tumor encapsulation, none versus complete & $2.25(1.21-4.16)$ & 0.010 & $1.56(0.74-3.28)$ & 0.243 \\
\hline Satellite lesion, yes versus no & $4.04(2.10-7.77)$ & $<0.001$ & $1.33(0.56-3.16)$ & 0.520 \\
\hline Vascular invasion, yes versus no & $2.77(1.46-5.24)$ & 0.002 & $1.93(0.96-3.88)$ & 0.065 \\
\hline Edmondson stage, III-IV versus I-II & $2.23(1.23-4.06)$ & 0.008 & NA & NA \\
\hline$B C L C$ stage, $B+C$ versus $0+A$ & $I .1 I(0.5 I-2.39)$ & 0.792 & NA & NA \\
\hline Preoperative CTC spheroid, $>16$ versus $\leq 16$ & $10.15(4.97-20.73)$ & $<0.001$ & $7.46(2.90-19.21)$ & $<0.001$ \\
\hline
\end{tabular}

\section{Spheroids Derived from EpCAM Positive} HCC Cells are Prone to Tumorigenesis

\section{and Lung Metastasis in vivo}

The effect of EpCAM positive HCC spheroids on tumor growth and potential to metastasize to the lungs in vivo was assessed. Spheroids derived from Huh7 (cultured on day 7), EpCAM-positive Huh7 and EpCAM-negative Huh7 cells were used for each group $(n=6)$. A total of 3 weeks after cell transplantation, tumor volume in the EpCAM-positive group grew more quickly compared with the Huh7 and EpCAM-negative groups. After 6 weeks, mice were sacrificed and tumors were removed and weighed. The tumor volumes and weights of the EpCAM-positive group were higher compared with the other two groups (Figure 6A-C). Immunohistochemistry analysis of Ki67, EpCAM and $\beta$-catenin protein expression in tumor tissues of the different groups was performed. Ki67, EpCAM and $\beta$-catenin proteins were more highly expressed in the EpCAM-positive group compared with the other groups (Figure 6D). These results suggested that spheroids derived from EpCAM-positive HCC cells exhibited stronger tumorigenicity in vivo, accompanied by enhanced expression of the proliferating cell antigen, $\mathrm{Ki} 67$, and abnormal activation of the Wnt $/ \beta$-catenin signaling pathway.

Furthermore, as demonstrated in Figure 6E, mice injected with EpCAM-positive Huh7 spheroids exhibited a higher number and larger metastatic nodules in the lung compared with the other two groups. These in vivo data support the conclusion that EpCAM-positive HCC cells exhibited increased survival and proliferative capacity, and thus increased tumor growth and metastasis.

\section{Discussion}

Metastasis from the primary tumor to other sites is the most common cause of cancer-associated death, and this is primarily driven by tumor cells circulating in the blood. ${ }^{30}$ The presence of CTCs in the peripheral blood may be assessed using a "liquid biopsy" approach, and thus, the study of CTCs has gained increasing attention in the field of cancer research. CTC molecular characterization offers the unique potential to improve our understanding of the biology of metastasis and resistance to established therapies, and analysis of these cells is a promising field for improving the current understanding of both advanced and early stage cancer. CTCs can be isolated from blood in a non-invasive manner and may be used to assess patients over time, as these cells can provide a significant amount of information on the patient's specific tumor biology and tumor cell dissemination. ${ }^{31}$ CTC enumeration has already proven useful in predicting the prognosis of patients with hepatocellular carcinoma, ${ }^{15}$ colon $^{32}$ and prostate cancer ${ }^{33}$ and cholangiocarcinoma. ${ }^{34}$ However, CTC detection, enumeration and molecular characterization are extremely challenging, as CTCs are very rare, and the amount of available sample can be limiting. 


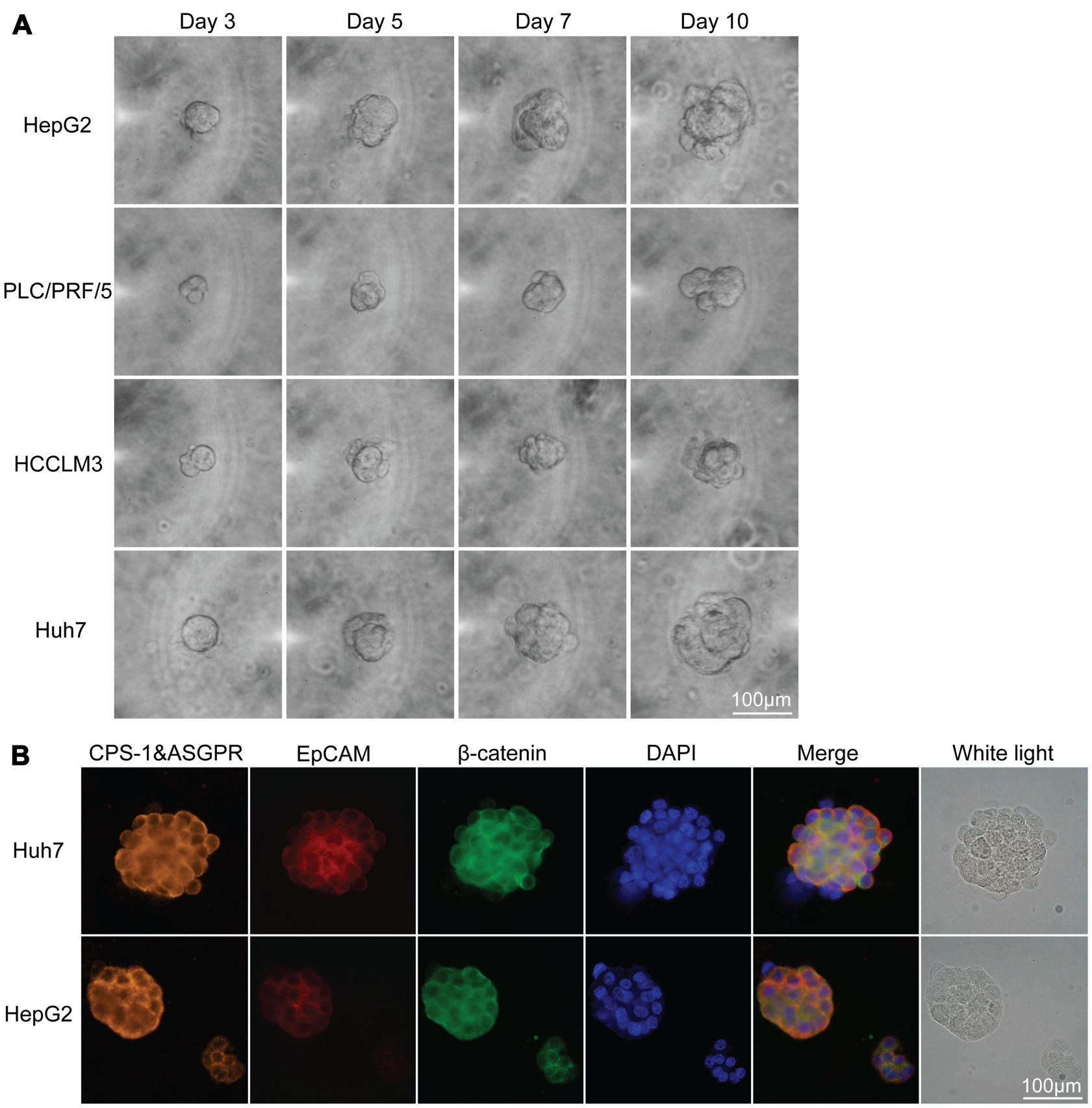

Figure 4 Culture and identification of CTC spheroids from the HCC cell lines. (A) Typical images of CTC spheroids from four HCC cell lines after different periods of culture. (B) Identification of CTC spheroids from HCC cell lines using immunofluorescence analysis.

Abbreviations: CTC, circulating tumor cell; HCC, hepatocellular carcinoma.

HCC is a primary liver cancer that is very challenging to treat due to the complex etiology and management. Currently, some interesting and encouraging results have been achieved in HCC/CTC detection, although our knowledge regarding the clinical relevance of CTCs in HCC lags behind that of the other major types of tumor. ${ }^{35}$ The heterogeneous nature of HCC and the lack of appropriate biomarkers have hampered patient prognosis and treatment stratification. ${ }^{36} \mathrm{~A}$ high degree of heterogeneity of CTCs, even amongst the same individual, has been observed when performing high-dimensional single CTC profiling, and by directly measuring gene expression in individual CTCs without the common practice of pooling such cells. However, several questions remain unanswered regarding the biology of CTCs, the optimal method to enumerate and characterize CTCs, and the path to regulatory and general clinical acceptance of technological platforms currently under development. 

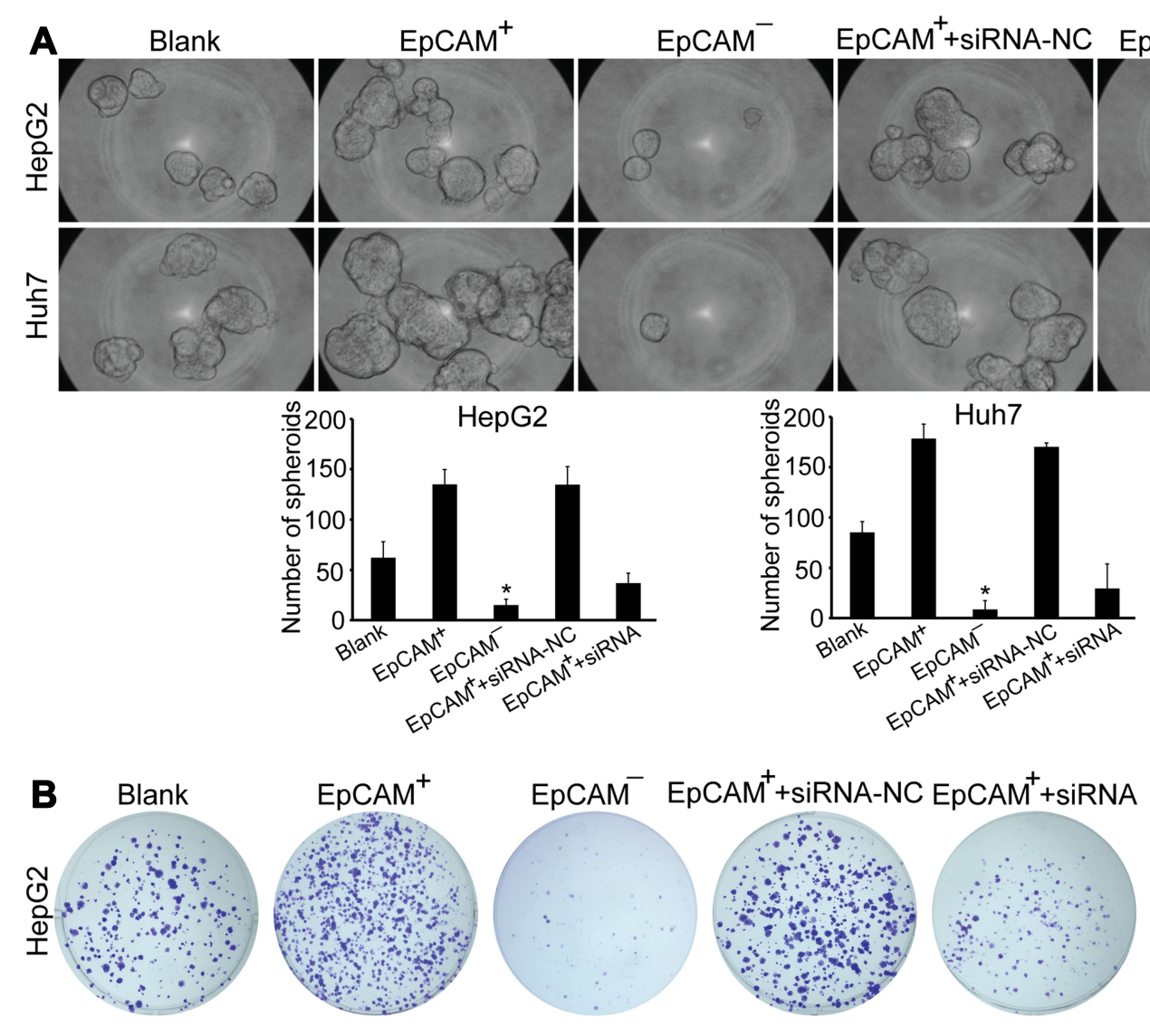

$\mathrm{EpCAM}^{-} \mathrm{EpCAM}^{+}+\mathrm{siRNA}^{-N C} \mathrm{EpCAM}^{+}+\mathrm{siRNA}^{-}$
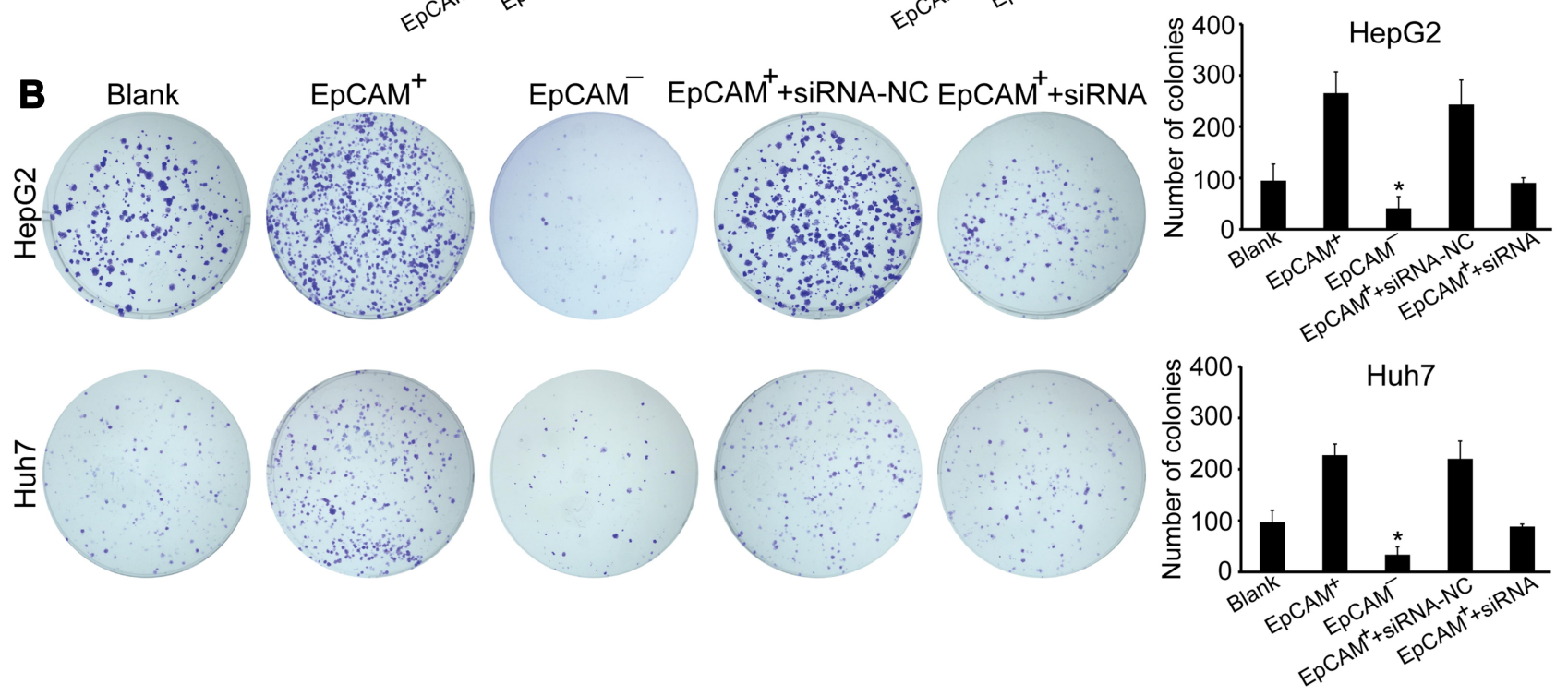

C

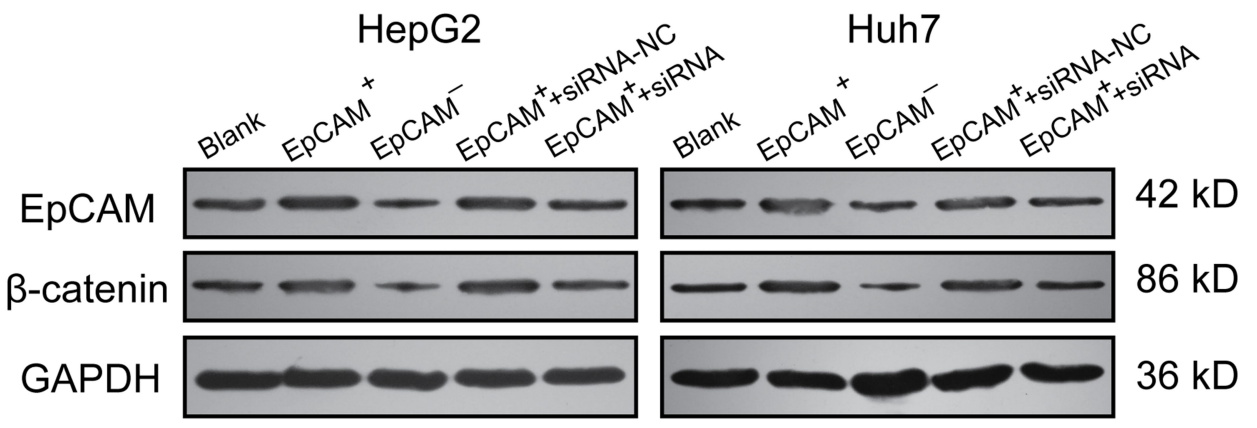

Figure 5 EpCAM/Wnt/ $\beta$-catenin contributes to CTC spheroid formation and survival. (A) CTCs from HCC cell lines formed spheroids on day 7 in culture with or without EpCAM. (B) Growth of CTC spheroids was assessed using a colony formation assay. (C) EpCAM and $\beta$-catenin expression in spheroids from HCC cell lines was assessed by Western blotting. ${ }^{*} \mathrm{P}<0.05$.

Abbreviations: CTC, circulating tumor cell; HCC, hepatocellular carcinoma; EpCAM, epithelial cell adhesion molecule.

Studies, including our previous and present study, have shown that there were vimentin-stained and/or CK-CTCs in patients with cancer. ${ }^{29,37,38}$ Since an unknown number of CTCs with an EMT phenotype may be missed by the current epithelial cell marker-based methods, ${ }^{39}$ the number of CTCs in cancer patients is probably considerably higher 

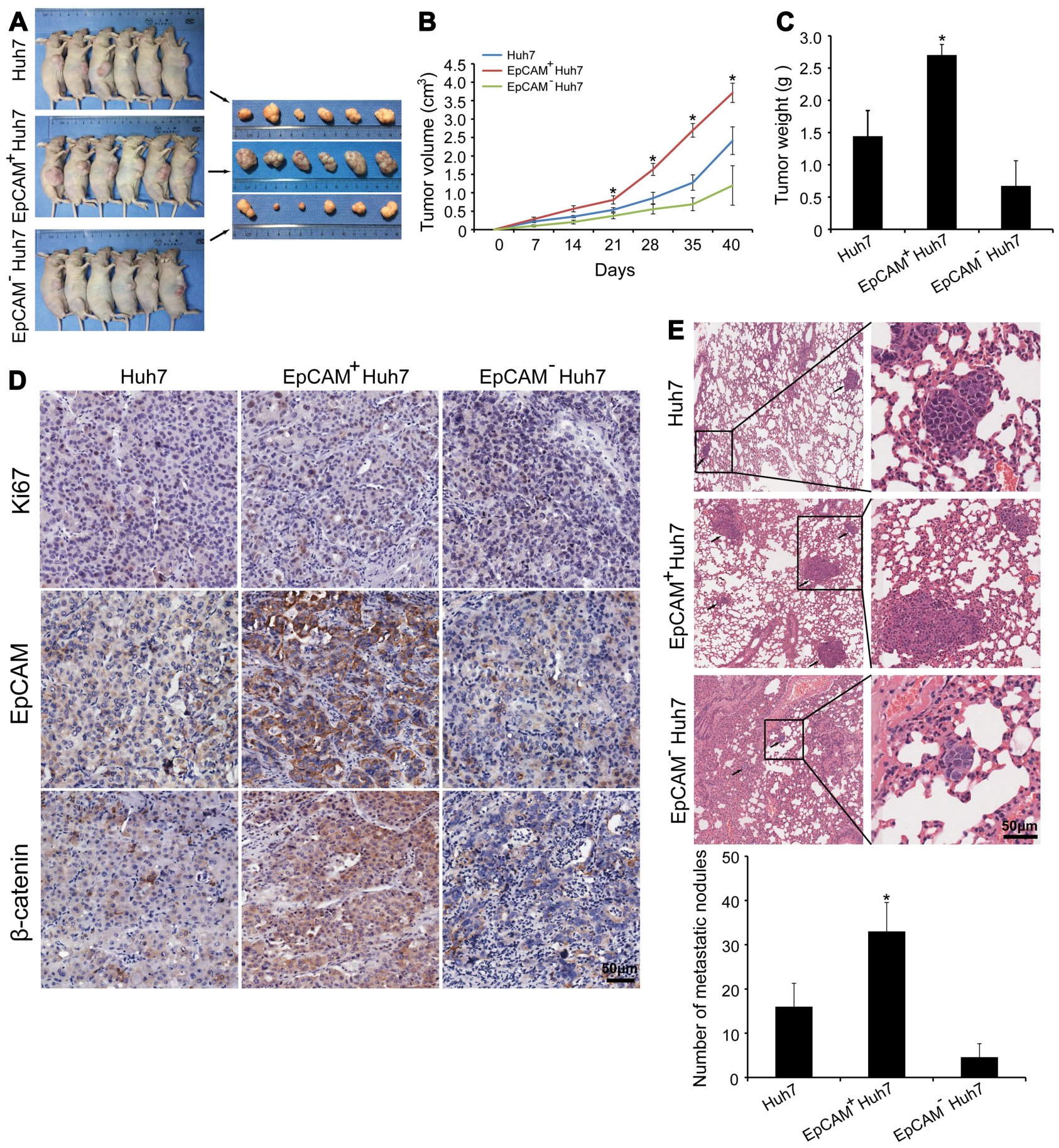

Figure 6 Spheroids derived from EpCAM positive HCC cells exhibit increased tumorigenesis and are more likely to metastasize to the lungs in vivo. (A) Spheroids derived from Huh7, EpCAM-positive Huh7 and EpCAM-negative Huh7 (cultured for 7 days) were subcutaneously injected in mice to establish a HCC xenograft model. $\mathrm{n}=6 \mathrm{mice}$ per group. (B and C) Tumor volume and weight was measured regularly. (D) Immunohistochemistry analysis was used to detect the expression of Ki67, EpCAM and $\beta$-catenin in tumor tissues in the HCC xenograft model. (E) Morphology of metastases to the lungs and H\&E staining of metastatic nodules in the lungs of nude mice 6 weeks after tail vein injection with spheroids derived from Huh7, EpCAM-positive Huh7 and EpCAM-negative Huh7 (cultured for 7 days). Number of metastatic nodules in the lungs of each mouse were counted and analyzed. $n=5$ mice per group. ${ }^{*} \mathrm{P}<0.05$.

Abbreviations: HCC, hepatocellular carcinoma; EpCAM, epithelial cell adhesion molecule.

than that reflected in clinical testing. ${ }^{40}$ Serving as a barrier to metastasis, cells normally undergo an apoptotic process termed "anoikis" a form of cell death due to loss of contact with the extracellular matrix or neighboring cells. ${ }^{41}$
Although thousands of tumor cells disseminate into the circulation, only a small population survives migration to establish secondary colonies. ${ }^{14,21,22}$ Due to the heterogeneity of tumor cells, apoptosis caused by anchorage- 
dependent anoikis and circulating shear forces, simple enumeration of CTC to evaluate prognostic potential is considered controversial.

Aggregates containing two or more CTCs (also known as circulating tumor microemboli) (CTC clusters; herein, CTC spheroids) have been known for decades to seed colonies with greater efficiency than individual CTCs. ${ }^{42}$ Recent data suggest that CTC clusters may possess a 50x greater metastatic potential than individual CTCs. ${ }^{43}$ The greater colonization efficiency of CTC clusters may be due to a number of factors, including protection against anoikis. $^{44}$ The spheroid-forming cells from primary tumors, such as breast cancer and ovarian cancer, showed stem-like properties and expressed their CSC markers. ${ }^{45,46}$ It is generally accepted that, similar to all stem cells, the tumor spheroid-forming cells are capable of proliferation, self-renewal and possess higher tumorigenicity. Beyond their role in metastasis, CTC spheroids may also serve as biomarkers for early detection, ${ }^{47}$ as prognostic markers, ${ }^{44,45}$ and may be used to noninvasively track changes in drug susceptibility in patients undergoing treatment. ${ }^{25}$

In the present study, spheroids formed from the CTCs in blood samples of patients with HCC were cultivated and enumerated using a 3D cell culture system. The 3D tumor cell culture model takes advantage of cell-to-cell communication, cell-to-matrix adhesion and more accurately replicates the physical characteristics of tumors, and thus better recreates the in vivo microenvironment and tumor biology. ${ }^{13}$ CTC spheroid enumeration can be used to more precise predict short-term recurrence of HCC in patients compared with conventional CTC enumeration. Further studies have shown that EpCAM may serve as key regulator of CTC spheroid-formation and survival by activating the $\mathrm{Wnt} / \beta$ catenin signaling pathway. EpCAM is a transmembrane glycoprotein that functions as a homophilic $\mathrm{Ca}^{2+}$-independent adhesion molecule expressed in almost all types of carcinomas. Recent studies suggested that EpCAM is upregulated in the majority of human epithelial carcinomas and its expression is correlated with de-differentiation and malignant proliferation of epithelial cells. ${ }^{48-50}$ In addition, EpCAM is used as a cancer stem cell marker, promoting tumor cell survival, proliferation and migration to establish secondary colonies by maintaining stem cell-like properties of HCC cells. ${ }^{51,52}$ The results of the present study showed that $\mathrm{EpCAM}$ and $\beta$-catenin were expressed in spheroids derived from HCC cells, and this was consistent with spheroids derived from HCC CTCs. The in vivo data also demonstrated that spheroids derived from EpCAM-positive HCC cells exhibited improved survival and proliferation, and consequently promoted tumor growth and metastasis. Upregulation of $\beta$-catenin and EpCAM expression was observed in the spheroids from HCC patients. Similar results were obtained in spheroids from HCC cell lines. Knockdown of EpCAM suppressed spheroid formation, survival and proliferation, and this was accompanied by a decrease in the expression of $\beta$-catenin. $\beta$-catenin is a key component of intercellular junctions and serves an essential role in the Wnt signaling pathway, its variable expression levels within primary tumors raise the possibility that it may demarcate tightly adherent groups of cells that may serve as precursors to CTC spheroids. EpCAM and $\mathrm{Wnt} / \beta$-catenin act as part of the same signaling pathway. $\mathrm{Wnt} / \beta$-catenin signaling serves a pivotal role in embryogenesis and the maintenance of stem cell growth, ${ }^{53}$ and it is activated during liver development/regeneration. ${ }^{54,55}$ EpCAM and Wnt/ $\beta$-catenin signaling are connected, and both serve a role in the maintenance of hepatic cancer stem cells. ${ }^{56}$ The results of the present study showed that $\mathrm{CTCs} / \mathrm{HCC}$ cells expressing EpCAM exhibited an improved ability to form spheroids in vitro and in vivo, and the Wnt/ $\beta$ catenin signaling pathway participated in cell aggregation and the maintenance of stem cell growth.

In summary, the present study demonstrated that CTC spheroid enumeration could more precisely predict the prognosis of patients with HCC compared with conventional CTC enumeration. EpCAM may serve a key role in the formation and survival of CTC spheroids, and it was dependent on the $\mathrm{Wnt} / \beta$-catenin signaling pathway. These data demonstrate that the model used in the present study may serve as a novel tool for predicting prognosis and anti-tumor drug screening, providing new insights into personalized therapy for patients with HCC.

\section{Data Sharing Statement}

The datasets used and/or analyzed during the present study are available from the corresponding author on reasonable request.

\section{Ethics Approval and Consent to Participate}

The use of human tissues, blood samples and clinical data was approved by the Biomedical Ethics Committee of Eastern Hepatobiliary Surgery Hospital, Second Military 
Medical University (Shanghai, China). All patients and healthy volunteers provided informed written consent, which was conducted in accordance with the declaration of Helsinki. All in vivo experiments were performed in accordance with guidelines of the Institutional Animal Care and Use Committee, and National and Institutional guidelines.

\section{Funding}

The present study was funded by the National Natural Science Foundation of China (grant no. 81301830).

\section{Disclosure}

The authors declare that they have no competing interests.

\section{References}

1. Bray F, Ferlay J, Soerjomataram I, Siegel RL, Torre LA, Jemal A. Global cancer statistics 2018: GLOBOCAN estimates of incidence and mortality worldwide for 36 cancers in 185 countries. CA Cancer J Clin. 2018;68(6):394-424. doi:10.3322/caac.21492

2. Llovet JM, Peña CE, Lathia CD, et al. Plasma biomarkers as predictors of outcome in patients with advanced hepatocellular carcinoma. Clin Cancer Res. 2012;18(8):2290-2300. doi:10.1158/ 1078-0432.CCR-11-2175

3. Soresi M, Terranova A, Licata A, et al. Surveillance program for diagnosis of $\mathrm{HCC}$ in liver cirrhosis: role of ultrasound echo patterns. Biomed Res Int. 2017;2017:4932759. doi:10.1155/2017/4932759

4. Kanda T, Goto T, Hirotsu Y, Moriyama M, Omata M. Molecular mechanisms driving progression of liver cirrhosis towards hepatocellular carcinoma in chronic hepatitis B and C infections: a review. Int J Mol Sci. 2019;20(6):1358. doi:10.3390/ijms20061358

5. Mazzaferro V, Lencioni R, Majno P. Early hepatocellular carcinoma on the procrustean bed of ablation, resection, and transplantation Semin Liver Dis. 2014;34(04):415-426. doi:10.1055/s-0034-1394365

6. Liccioni A, Reig M, Bruix J. Treatment of hepatocellular carcinoma. Dig Dis. 2014;32(5):554-563. doi:10.1159/000360501

7. Bruix J, Han KH, Gores G, Llovet JM, Mazzaferro V. Liver cancer: approaching a personalized care. J Hepatol. 2015;62(1):S144-156. doi:10.1016/j.jhep.2015.02.007

8. Qu K, Wang Z, Fan H, et al. MCM7 promotes cancer progression through cyclin D1-dependent signaling and serves as a prognostic marker for patients with hepatocellular carcinoma. Cell Death Dis. 2017;8(2):e2603. doi:10.1038/cddis.2016.352

9. Atanassov BS, Dent SY. Usp22 regulates cell proliferation by deubiquitinating the transcriptional regulator fbp1. EMBO Rep. 2011;12 (9):924-930. doi:10.1038/embor.2011.140

10. Kaseb AO, Hassan M, Lacin S, et al. Evaluating clinical and prognostic implications of Glypican-3 in hepatocellular carcinoma. Oncotarget. 2016;7(43):69916-69926. doi:10.18632/ oncotarget.12066

11. Li J, Shi LH, Zhang XF, et al. pERK/pAkt phenotyping in circulating tumor cells as a biomarker for sorafenib efficacy in patients with advanced hepatocellular carcinoma. Oncotarget. 2016;7 (3):2646-2659. doi:10.18632/oncotarget.6104

12. Massagué J, Obenauf AC. Metastatic colonization by circulating tumour cells. Nature. 2016;529(7586):298-306. doi:10.1038/ nature 17038

13. Lovitt CJ, Shelper TB, Avery VM. Miniaturized three-dimensional cancer model for drug evaluation. Assay Drug Dev Technol. 2013;11 (7):435-448. doi:10.1089/adt.2012.483
14. Yu M, Ting DT, Stott SL, et al. RNA sequencing of pancreatic circulating tumour cells implicates WNT signalling in metastasis. Nature. 2012;487(7408):510-513. doi:10.1038/nature11217

15. Guo W, Sun YF, Shen MN, et al. Circulating tumor cells with stem-like phenotypes for diagnosis, prognosis, and therapeutic response evaluation in hepatocellular carcinoma. Clin Cancer Res. 2018;24(9):2203-2213. doi:10.1158/1078-0432.CCR-17-1753

16. Cohen SJ, Punt CJ, Iannotti N, et al. Relationship of circulating tumor cells to tumor response, progression-free survival, and overall survival in patients with metastatic colorectal cancer. J Clin Oncol. 2008;26(19):3213-3221. doi:10.1200/JCO.2007.15.8923

17. Cristofanilli M, Budd GT, Ellis MJ, et al. Circulating tumor cells, disease progression, and survival in metastatic breast cancer. $N$ Engl $J$ Med. 2004;351(8):781-791. doi:10.1056/NEJMoa040766

18. Lin SY, Chang SC, Lam S, et al. Prospective molecular profiling of circulating tumor cells from patients with melanoma receiving combinatorial immunotherapy. Clin Chem. 2020;66(1):169-177. doi:10.1373/clinchem.2019.307140

19. Ruck P, Wichert G, Handgretinger R, Kaiserling E. Ep-CAM in malignant liver tumours. $J$ Pathol. 2000;191(1):102-103. doi:10.1002/(SICI)1096-9896(200005)191:1<102::AID-PATH542>3. $0 . \mathrm{CO} ; 2-\mathrm{X}$

20. Yamashita T, Forgues M, Wang W, et al. EpCAM and alpha-fetoprotein expression defines novel prognostic subtypes of hepatocellular carcinoma. Cancer Res. 2008;68(5):1451-1461. doi:10.1158/0008-5472.CAN-07-6013

21. Duda DG, Duyverman AM, Kohno M, et al. Malignant cells facilitate lung metastasis by bringing their own soil. Proc Natl Acad Sci USA. 2010;107(50):21677-21682. doi:10.1073/pnas.1016234107

22. Mani SA, Guo W, Liao MJ, et al. The epithelial-mesenchymal transition generates cells with properties of stem cells. Cell. 2008;133 (4):704-715. doi:10.1016/j.cell.2008.03.027

23. Sun B, Hu CL, Yang ZB, et al. Midkine promotes hepatocellular carcinoma metastasis by elevating anoikis resistance of circulating tumor cells. Oncotarget. 2017;8(20):32523-32535. doi:10.18632/ oncotarget. 15808

24. Liu HY, Qian HH, Zhang XF, et al. Improved method increases sensitivity for circulating hepatocellular carcinoma cells. World $J$ Gastroenterol. 2015;21(10):2918-2925. doi:10.3748/wjg.v21. i10.2918

25. Yu M, Bardia A, Aceto N, et al. Cancer therapy. Ex vivo culture of circulating breast tumor cells for individualized testing of drug susceptibility. Science. 2014;345(6193):216-220. doi:10.1126/ science. 1253533

26. Rubbia-Brandt L, Mentha G, Desmoulière A, et al. Hepatic stellate cells reversibly express alpha-smooth muscle actin during acute hepatic ischemia. Transplant Proc. 1997;29(5):2390-2395. doi:10.1016/S0041-1345(97)00415-6

27. Firtina Karagonlar Z, Koç D, Şahin E, et al. Effect of adipocyte-secreted factors on EpCAM+/CD133+ hepatic stem cell population. Biochem Biophys Res Commun. 2016;474(3):482-490. doi:10.1016/j.bbrc.2016.04.137

28. Xia H, Ooi LL, Hui KM, Gottardi C. MiR-214 targets $\beta$-catenin pathway to suppress invasion, stem-like traits and recurrence of human hepatocellular carcinoma. PLoS One. 2012;7(9):e44206. doi:10.1371/journal.pone.0044206

29. Xu W, Cao L, Chen L, et al. Isolation of circulating tumor cells in patients with hepatocellular carcinoma using a novel cell separation strategy. Clin Cancer Res. 2011;17(11):3783-3793. doi:10.1158/ 1078-0432.CCR-10-0498

30. Zhong X, Zhang H, Zhu Y, et al. Circulating tumor cells in cancer patients: developments and clinical applications for immunotherapy. Mol Cancer. 2020;19(1):15. doi:10.1186/s12943-020-1141-9

31. Lianidou ES, Strati A, Markou A. Circulating tumor cells as promising novel biomarkers in solid cancers. Crit Rev Clin Lab Sci. 2014;51 (3):160-171. doi:10.3109/10408363.2014.896316 
32. Meropol NJ. The significance of circulating tumor cells as prognostic markers for colon cancer. Clin Adv Hematol Oncol. 2009;7 (4):247-248.

33. de Bono JS, Scher HI, Montgomery RB, et al. Circulating tumor cells predict survival benefit from treatment in metastatic castration-resistant prostate cancer. Clin Cancer Res. 2008;14 (19):6302-6309. doi:10.1158/1078-0432.CCR-08-0872

34. Yang JD, Campion MB, Liu MC, et al. Circulating tumor cells are associated with poor overall survival in patients with cholangiocarcinoma. Hepatology. 2016;63(1):148-158. doi:10.1002/ hep. 27944

35. Zhang Y, Li J, Cao L, Xu W, Yin Z. Circulating tumor cells in hepatocellular carcinoma: detection techniques, clinical implications, and future perspectives. Semin Oncol. 2012;39(4):449-460. doi:10.1053/j.seminoncol.2012.05.012

36. Dong LQ, Peng LH, Ma LJ, et al. Heterogeneous immunogenomic features and distinct escape mechanisms in multifocal hepatocellular carcinoma. J Hepatol. 2020;72(5):896-908. doi:10.1016/j. jhep.2019.12.014

37. Lecharpentier A, Vielh P, Perez-Moreno P, Planchard D, Soria JC, Farace F. Detection of circulating tumour cells with a hybrid (epithelial/mesenchymal) phenotype in patients with metastatic non-small cell lung cancer. Br J Cancer. 2011;105(9):1338-1341. doi:10.1038/ bjc. 2011.405

38. Pecot CV, Bischoff FZ, Mayer JA, et al. A novel platform for detection of $\mathrm{CK}+$ and CK- CTCs. Cancer Discov. 2011;1 (7):580-586. doi:10.1158/2159-8290.CD-11-0215

39. Riethdorf S, Fritsche H, Müller V, et al. Detection of circulating tumor cells in peripheral blood of patients with metastatic breast cancer: a validation study of the CellSearch system. Clin Cancer Res. 2007;13(3):920-928. doi:10.1158/1078-0432.CCR-06-1695

40. Barrière G, Tartary M, Rigaud M. Epithelial mesenchymal transition: a new insight into the detection of circulating tumor cells. ISRN Oncol. 2012;2012:382010.

41. Kim YN, Koo KH, Sung JY, Yun UJ, Kim H. Anoikis resistance: an essential prerequisite for tumor metastasis. Int $J$ Cell Biol. 2012;2012:306879. doi:10.1155/2012/306879

42. Umer M, Vaidyanathan R, Nguyen NT, Shiddiky MJA. Circulating tumor microemboli: progress in molecular understanding and enrichment technologies. Biotechnol Adv. 2018;36(4):1367-1389. doi:10.1016/j.biotechadv.2018.05.002

43. Aceto N, Bardia A, Miyamoto DT, et al. Circulating tumor cell clusters are oligoclonal precursors of breast cancer metastasis. Cell. 2014;158(5):1110-1122. doi:10.1016/j.cell.2014.07.013

44. Hou JM, Krebs MG, Lancashire L, et al. Clinical significance and molecular characteristics of circulating tumor cells and circulating tumor microemboli in patients with small-cell lung cancer. J Clin Oncol. 2012;30(5):525-532. doi:10.1200/JCO.2010.33.3716
45. Ponti D, Costa A, Zaffaroni N, et al. Isolation and in vitro propagation of tumorigenic breast cancer cells with stem/progenitor cell properties. Cancer Res. 2005;65(13):5506-5511. doi:10.1158/00085472.CAN-05-0626

46. Zhang S, Balch C, Chan MW, et al. Identification and characterization of ovarian cancer-initiating cells from primary human tumors. Cancer Res. 2008;68(11):4311-4320. doi:10.1158/0008-5472.CAN08-0364

47. Carlsson A, Nair VS, Luttgen MS, et al. Circulating tumor microemboli diagnostics for patients with non-small-cell lung cancer. J Thorac Oncol. 2014;9(8):1111-1119. doi:10.1097/ JTO.0000000000000235

48. Osta WA, Chen Y, Mikhitarian K, et al. EpCAM is overexpressed in breast cancer and is a potential target for breast cancer gene therapy. Cancer Res. 2004;64(16):5818-5824. doi:10.1158/0008-5472.CAN04-0754

49. Mukherjee S, Richardson AM, Rodriguez-Canales J, et al. Identification of EpCAM as a molecular target of prostate cancer stroma. Am J Pathol. 2009;175(6):2277-2287. doi:10.2353/ ajpath.2009.090013

50. Kimura O, Takahashi T, Ishii N, et al. Characterization of the epithelial cell adhesion molecule (EpCAM) + cell population in hepatocellular carcinoma cell lines. Cancer Sci. 2010;101(10):2145-2155. doi:10.1111/j.1349-7006.2010.01661.x

51. Yamashita T, Ji J, Budhu A, et al. EpCAM-positive hepatocellular carcinoma cells are tumor-initiating cells with stem/progenitor cell features. Gastroenterology. 2009;136(3):1012-1024. doi:10.1053/j. gastro.2008.12.004

52. Kim MY, Oskarsson T, Acharyya S, et al. Tumor self-seeding by circulating cancer cells. Cell. 2009;139(7):1315-1326. doi:10.1016/j. cell.2009.11.025

53. Reya T, Clevers H. Wnt signalling in stem cells and cancer. Nature. 2005;434(7035):843-850. doi:10.1038/nature03319

54. Micsenyi A, Tan X, Sneddon T, Luo JH, Michalopoulos GK, Monga SP. Beta-catenin is temporally regulated during normal liver development. Gastroenterology. 2004;126(4):1134-1146. doi:10.1053/j.gastro.2003.12.047

55. Russell JO, Monga SP. Wnt/ $\beta$-catenin signaling in liver development, homeostasis, and pathobiology. Annu Rev Pathol. 2018;13 (1):351-378. doi:10.1146/annurev-pathol-020117-044010

56. Yang W, Yan HX, Chen L, et al. Wnt/beta-catenin signaling contributes to activation of normal and tumorigenic liver progenitor cells. Cancer Res. 2008;68(11):4287-4295. doi:10.1158/0008-5472.CAN07-6691
OncoTargets and Therapy

\section{Publish your work in this journal}

OncoTargets and Therapy is an international, peer-reviewed, open access journal focusing on the pathological basis of all cancers, potential targets for therapy and treatment protocols employed to improve the management of cancer patients. The journal also focuses on the impact of management programs and new therapeutic agents and protocols on patient perspectives such as quality of life, adherence and satisfaction. The manuscript management system is completely online and includes a very quick and fair peer-review system, which is all easy to use. Visit http://www.dovepress.com/ testimonials.php to read real quotes from published authors. 